\title{
No increased chromosome breakage in three Bloom's syndrome heterozygotes
}

\author{
EVELYN MEYER KUHN AND EEVA THERMAN \\ From the Department of Medical Genetics, University of Wisconsin, Madison, Wisconsin 53706, USA
}

SUMMARY The frequency of chromosome aberrations in the lymphocytes of three established heterozygotes for the Bloom's syndrome gene (ages 67, 57, 46) was compared to that in controls (ages 68, 67, 61, 46, 34). The main part of the study was done on coded slides. No difference was found between the heterozygotes and the control group, except for one control (aged 46) who had a significantly higher number of chromosome aberrations than the others.

Individuals with Bloom's syndrome, which is caused by an autosomal recessive gene (bl), have a tendency to chromosomal abnormalities and a predisposition to malignant disease (German, 1969). Whether chromosome breakage and incidence of cancer are also increased in heterozygotes is so far an open question. It has been reported that $\mathrm{bl} /+$ cells may show an increase in chromosome breakage and the frequency of mitotic chiasmata (symmetrical, homologous chromatid exchanges) as compared with $+l+$ cells (German, 1969, 1972, 1973a, b). Hustinx et al. (1977), on the other hand, found no significant difference in the frequency of chromosome aberrations between four heterozygotes and normal people, and no mitotic chiasmata were observed in 592 heterozygote cells.

In the present study, three known heterozygotes from a family with two members with Bloom's syndrome have been compared with controls of about the same average age. The family is not of Jewish origin, and the parents are second cousins (Fig. 1).

\section{Materials and methods}

Lymphocyte cultures were prepared according to a modification of the usual Moorhead technique, and the slides were stained with azur A. The following people were investigated (Fig. 1): (1) The parents (IV.1 and IV.2) of two children with Bloom's syndrome (cases 22 and 23 in German, 1969). Cytogenetic observations on these patients have been reported by Kuhn $(1974,1976,1978)$ and by Therman and Kuhn (1976); (2) the maternal grandparents (III.1 and MI.2). The grandmother is a known heterozygote, while the grandfather is unrelated and may Received for publication 20 July 1978

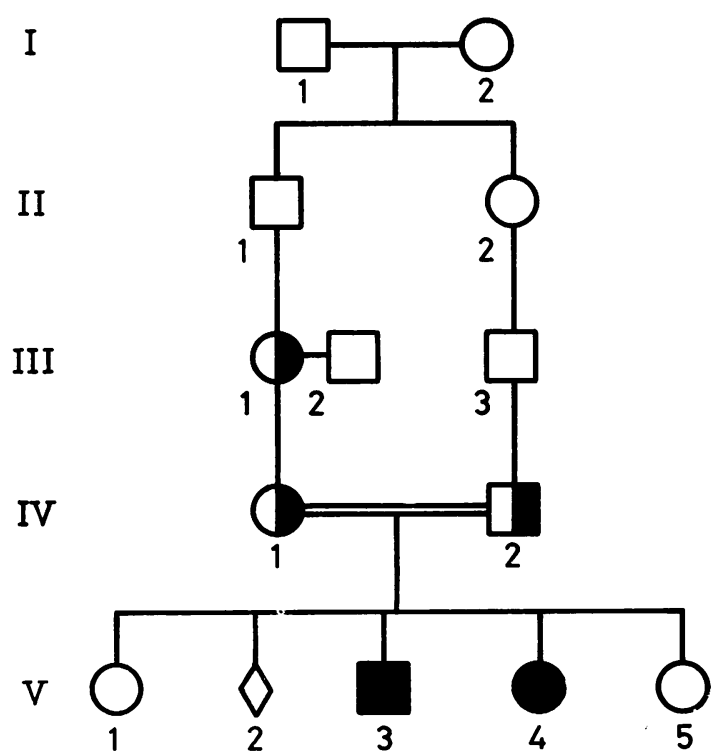

Fig. 1 Pedigree of family with two members with Bloom's syndrome and three known heterozygotes.

be presumed not to carry the bl gene; (3) two unaffected sisters (V.1 and V.5); and (4) two male and two female controls.

Only cells with at least 45 centromeres were included, and the cells with a chromosome structural abnormality were fully analysed. Chromosome or chromatid gaps were not scored. Breaks were only included if the fragment was clearly displaced (Fig. 2a). Polyploid cells with or without diplochromosomes were excluded.

The study was done in three parts (Table 1). First, the chromosomes of the parents were examined. 


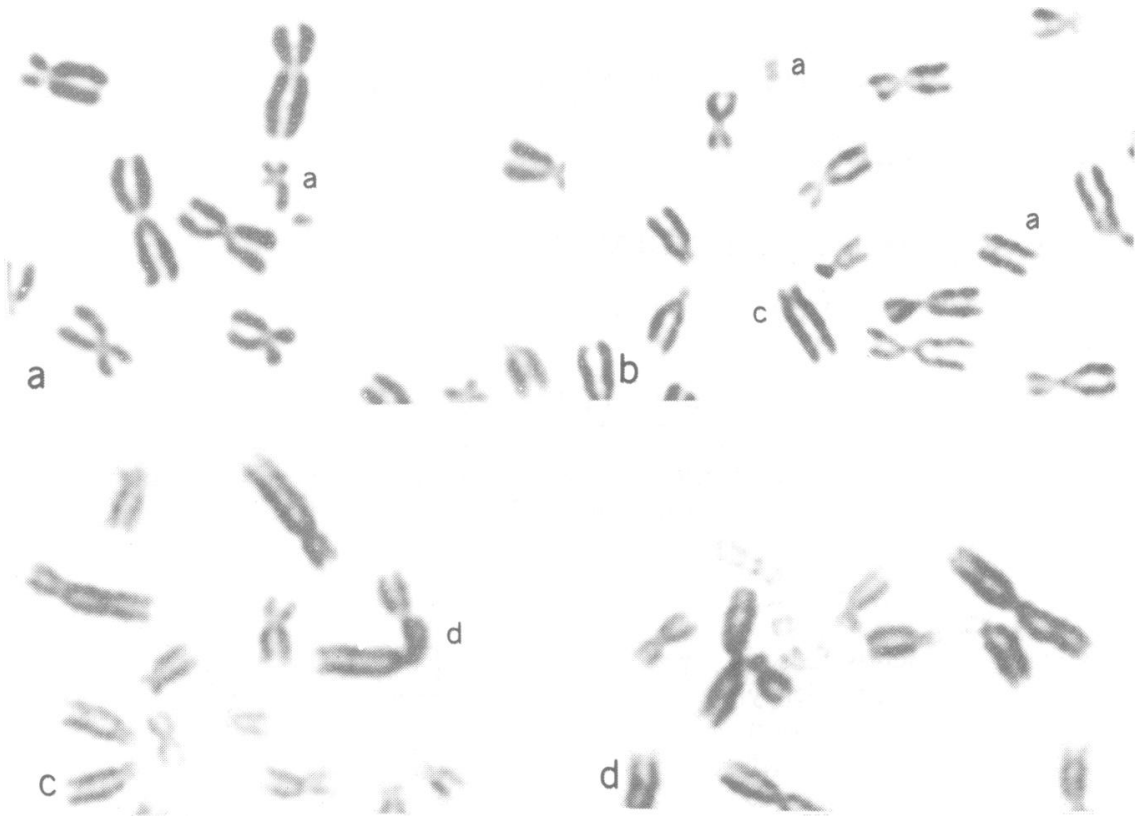

Fig. 2 Sample of chromosome anomalies. (a) Chromatid break (KP). (b) Two acentric and one centric fragment (IV.1). (c) Dicentric chromosome (FD). (d) Three out-of-phase chromosomes (IV.2). (a = acentric fragment; $c=$ centric fragment $; d=$ dicentric chromosome).

Table 1 Frequencies of cells with chromosome aberrations in Bloom's syndrome heterozygotes and normal controls

\begin{tabular}{|c|c|c|c|}
\hline Experiment & Cases studied & $\begin{array}{l}\text { Cells } \\
\text { with } \\
\text { aberrations }\end{array}$ & $\begin{array}{l}\text { without } \\
\text { aberrations }\end{array}$ \\
\hline $\begin{array}{l}\text { A } \\
\text { Non-coded } \\
\text { B }\end{array}$ & $\begin{array}{l}\text { Parents bl/t+ } \\
\text { (initial study) }\end{array}$ & 17 & 599 \\
\hline Coded & $\begin{array}{l}\text { Parents bl } /+ \\
\text { Controls }+/+ \\
\text { Parents bl } /+ \\
\text { Controls }+1+ \\
\text { (excluding FD) }\end{array}$ & $\begin{array}{r}8 \\
12 \\
8 \\
5\end{array}$ & $\begin{array}{l}472 \chi_{1}^{2}=0.460 * \\
468 P^{*}=0.50 \\
472 \chi_{1}^{2}=0.002 \\
355 P=0.97\end{array}$ \\
\hline $\mathbf{C}$ & & & \\
\hline Coded & $\begin{array}{l}\text { Grandmother bl } /+ \\
\text { Grandfather }+1+\end{array}$ & $\begin{array}{l}9 \\
7\end{array}$ & $\begin{array}{l}291 \chi_{1}^{2}=0.064 \\
293 \mathrm{P}=0.80\end{array}$ \\
\hline Total data & $\begin{array}{l}\text { Heterozygotes } \mathrm{bl} /+ \\
\text { Controls }+/+\end{array}$ & $\begin{array}{l}34 \\
19\end{array}$ & $\begin{aligned} 1362 \chi_{1}^{2} & =0.021 \\
761 \mathrm{P} & =0.89\end{aligned}$ \\
\hline
\end{tabular}

*All $\chi^{2}$ were done with Yates correction.

Next, a comparison of the parents and the four controls was performed on coded slides from lymphocyte cultures which had been grown simultaneously. Forty cells were checked from six slides of each of the parents and from three slides of the controls. Another study using coded slides was done on the grandparents and on an unaffected sister
(V.1). For each person, 60 cells were checked from each of five slides. The other unaffected sister was studied separately.

\section{Results}

During the initial examination of the parents chromosomes, a number of aberrations, including one mitotic chiasma in the father, were found. If. general, the father seemed to show a higher frequenc 8 of chromosome aberrations than the average of $0.8 \%$ found in our laboratory. This frequency was determined from 2324 cells fully analysed for the study of Trunca Doyle (1976). A total of 19 anomas. lies was found in these cells which did not include an mitotic chiasmata (C. Trunca Doyle, unpublishe@ data). All the people were less than 40 years old, 800 were normal controls, and 85 were patients with idiow pathic mental retardation and at least three othe anomalies. None suffered from a chromosome breaking disease. Since the parents in the preserf study were older adults, older controls were used if experiment $B$ (Table 1). In experiment $C$, the grand father served as a control for the heterozygous grandmother. The results are shown in Tables 1 an 2 , and examples of chromosome aberrations are illustrated in Fig. 2. 
Table 2 Types of chromosome abnormalities in Bloom's syndrome heterozygotes and in normal controls (see Fig. 1)

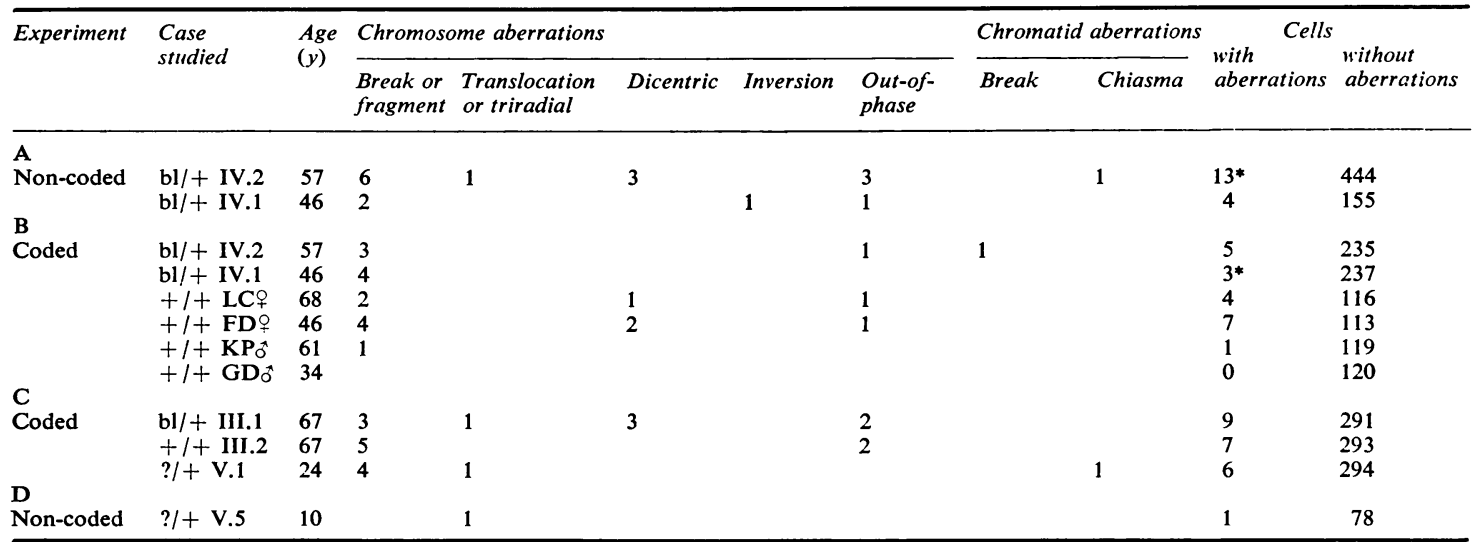

* Two abnormalities in one cell.

In experiment $\mathrm{A}$, one of the controls (FD) had a significantly higher incidence of cells with chromosome abnormalities than the other three $(P=0.02)$ (Table 1). The parents were compared with the controls both including and excluding control FD (Table 1), but no significant difference was found. Neither was there any difference between the grandparents.

No significant difference existed in the aberration frequency between the initial study of the parents and the coded experiment $\mathrm{B}(\mathrm{P}=\mathbf{0} \cdot 32)$ (Table 1). The data for the parents were therefore pooled.

The total data for $\mathrm{bl} /+$ heterozygotes (the parents plus the grandmother) were then compared with the total data for the $+/+$ homozygotes (normal controls plus the grandfather). The aberration frequency for these two groups was not significantly different (Table 1). The mean age of the three heterozygotes and five controls was 55.8 years and the frequency of cells with chromosome structural aberrations in them was $2.4 \%$.

One mitotic chiasma was found in 697 cells of the father or in a total of 1396 cells of the heterozygotes. In one of the two unaffected sisters, 6 of 300 metaphases showed abnormalities, one of which was a mitotic chiasma, while the corresponding frequency in the other sister was one abnormality in 79 metaphases.

Apart from the individual cells with chromosome aberrations, all the 12 persons studied had a normal chromosome constitution (Table 2).

\section{Discussion}

The three Bloom's syndrome heterozygotes in the present study did not have a higher frequency of chromosome aberrations than the controls, whose average age was about the same $(2.4 \%)$. In people under 40 years old the corresponding number in our laboratory was $0.8 \%$. The value of some $2.4 \%$ cells with abnormalities is within the range reported for normal people by other groups (Lubs and Samuelson, 1967; Littlefield and Goh, 1973; Aula and von Koskull, 1976; Aymé et al., 1976). However, it is difficult to compare results obtained by different groups, since the criteria for scoring abnormalities vary greatly. That there is a considerable variability among normal people, particularly women, as illustrated by the present control FD who had a high aberration frequency, has been reported by Littlefield and Goh (1973). Older people appear to have higher rates of chromosome abnormalities (Mattevi and Salzano, 1975; Aymé et al., 1976) and, therefore, it is important to use controls in the same age range.

The occurrence of mitotic chiasmata in the lymphocytes is a characteristic feature of Bloom's syndrome (German et al., 1965; Patau and Therman, 1969; Therman and Kuhn, 1976). Their incidence varies between people and/or cultures from $0.5 \%$ to $14 \%$ of the cells (German, 1974). There have been reports that mitotic chiasmata occur more frequently in lymphocytes of heterozygotes than of normal people (German, 1969, 1972). In the present study, one chiasma was found in 697 cells in the father, which amounts to one chiasma in 1396 cells from the three known heterozygotes. This is in the same range as the average of one chiasma in 1000 cells found in our laboratory for people who do not suffer from a chromosome-breaking disease (Therman and Kuhn, 1976). A somewhat lower frequency, namely 3 chiasmata in 29709 cells from 
normal people, has been reported by Littlefield and Goh (1973).

The frequency of sister chromatid exchanges in cells of patients with Bloom's syndrome is greatly increased over that in normal cells (Chaganti et al., 1974). According to several investigators (Chaganti et al., 1974; Bartram et al., 1976; Sperling et al., 1976), the frequency of sister chromatid exchanges in heterozygous cells is within normal limits. Hustinx et al. (1977), on the other hand, reported that the rate was slightly increased in several heterozygotes, but that the same people showed no increase in chromosome aberrations. One of the aims of cytological studies on Bloom's syndrome heterozygotes has been to find a phenomenon which could be used to identify them. These hopes have not been fulfilled so far. It is possible that the frequency of chromosome aberrations varies in different heterozygotes, but so it does in normal people used as controls. The three heterozygotes in the present study certainly could not have been diagnosed on the basis of chromosome abnormalities, and in previous studies, controls of the same age group have not been used.

Patients suffering from Bloom's syndrome clearly show a predisposition to malignant disease (German, 1972). Numerous cases of cancer have also been found in unaffected family members (German, 1974). However, it remains to be determined whether the heterozygotes really have a significantly increased probability of developing cancer, as has been reported for two other diseases, Fanconi's anaemia and ataxia telangiectasia, (Swift, 1971; Swift et al., 1976), which are also characterised by increased chromosome breakage and predisposition to cancer in the homozygotes.

This is paper no 2231 from the Genetics Laboratory, University of Wisconsin. The work was aided by grant GM 22881 from the National Institutes of Health (Washington, DC). For the blood samples we are grateful to Dr John M. Opitz. The photography was done by Mr Walter Kugler, Jr.

\section{References}

Aula, P., and von Koskull, H. (1976). Distribution of spontaneous chromosome breaks in human chromosomes. Human Genetics, 32, 143-148.

Aymé, S., Mattei, J. F., Mattei, M. G., Aurran, Y., and Giraud, F. (1976). Nonrandom distribution of chromosome breaks in cultured lymphocytes of normal subjects. Human Genetics, 31, 161-175.

Bartram, C. R., Koske-Westphal, T., and Passarge, E. (1976). Chromatid exchanges in ataxia telangiectasia, Bloom syndrome, Werner syndrome, and xeroderma pigmentosum. Annals of Human Genetics, 40, 79-86.
Chaganti, R. S. K., Schonberg, S., and German, J. (1974 A manyfold increase in sister chromatid exchanges in: Bloom's syndrome lymphocytes. Proceedings of th National Academy of Sciences of the United States America, 71, 4508-4512.

German, J. (1969). Chromosomal breakage syndromes. Birt Defects: Original Article Series, 5, 117-131.

German, J. (1972). Genes which increase chromosoma instability in somatic cells and predispose to cancer. In Progress in Medical Genetics, Vol. 8, pp. 61-101. Ed. bø A. G. Steinberg and A. G. Bearn. Grune and Stratton, New York and London.

German, J. (1973a). Genetic disorders associated with chromosomal instability and cancer. Journal of Investiga $\vec{\omega}$ tive Dermatology, 60, 427-434. German, J. (1973b). Oncogenic implications of chromosoms
instability. Hospital Practice, 8, 93-104.

German, J. (1974). Bloom's syndrome. II. The prototype of human genetic disorders predisposing to chromosome instability and cancer. In Chromosomes and Cancers pp. 601-617. Ed. by J. German. John Wiley, New York. $\frac{1}{0}$

German, J., Archibald, R., and Bloom, D. (1965). Chromo somal breakage in a rare and probably genetically deter mined syndrome of man. Science, 148, 506-507.

Hustinx, T. W. J., Ter Haar, B. G. A., Scheres, J. C., Rutten, F. J., Weemaes, C. M. R., Hoppe, R. L. E., and Janssen A. H. (1977). Bloom's syndrome in two Dutch families\$ Clinical Genetics, 12, 85-96.

Kuhn, E. M. (1974). Nonrandom localization of mitotia crossing-over in Bloom's syndrome. Genetics, 77, s37-s38.

Kuhn, E. M. (1976). Localization by Q-banding of mitotiv chiasmata in cases of Bloom's syndrome. Chromosoma, 570 $1-11$.

Kuhn, E. M. (1978). Mitotic chiasmata and other quadri radials in mitomycin C-treated Bloom's syndrome lym phocytes. Chromosoma, 66, 287-297.

Littlefield, L. G., and Goh, K.-O. (1973). Cytogenetic studies in control men and women. I. Variations in aberratio frequencies in 29,709 metaphases from 305 cultures obtained over a three-year period. Cytogenetics and Celt Genetics, 12, 17-34.

Lubs, H. A., and Samuelson, J. (1967). Chromosome abnormalities in lymphocytes from normal human subjects. A3 study of 3,720 cells. Cytogenetics, 6, 402-411.

Mattevi, M. S., and Salzano, F. M. (1975). Senescence and human chromosome changes. Humangenetik, 27, 1-8.

Patau, K., and Therman, E. (1969). Mitotic crossing-over im man. Genetics, 61, s45-s46.

Sperling, K., Goll, U., Kunze, J., Lüdtke, E.-K., Tolksdorf, M., and Obe, G. (1976). Cytogenetic investigations in new case of Bloom's syndrome. Human Genetics, 31, 47-52

Swift, M. (1971). Fanconi's anemia in the genetics of neoo plasia. Nature, 230, 370-373.

Swift, M., Sholman, L., Perry, M., and Chase, C. (1976) N Malignant neoplasms in the families of patients with ataxia-telangiectasia. Cancer Research, 36, 209-215.

Therman, E., and Kuhn, E. M. (1976). Cytological demon stration of mitotic crossing-over in man. Cytogenetics and Cell Genetics, 17, 254-267.

Trunca Doyle, C. (1976). The cytogenetics of 90 patients with idiopathic mental retardation/malformation syndromes and of 90 normal subjects. Human Genetics, 33, 131-146.

Requests for reprints to Professor E. Theiman Laboratory of Genetics, 514 B Genetics Building University of Wisconsin, Madison, Wisconsin 53706 USA. 